\title{
DE
}

DE GRUYTER OPEN

Arch. Min. Sci., Vol. 61 (2016), No 1, p. 199-216

Electronic version (in color) of this paper is available: http://mining.archives.pl

DOI 10.1515/amsc-2016-0015

MARILENA CARDU*,**, SERGIO DIPIETROMARIA***, PIERPAOLO ORESTE*,**,1

\section{SUB-LEVEL STOPING IN AN UNDERGROUND LIMESTONE QUARRY: AN ANALYSIS OF THE STATE OF STRESS IN AN EVOLUTIONARY SCENARIO}

\section{WYBIERANIE PODPOZIOMOWE WAPIENIA W PODZIEMNYCH KAMIENIOLOMACH: ANALIZA STANÓW NAPRĘŻEŃ W SCENARIUSZU ROZWOJOWYM}

The aim of this study was to evaluate the state of stress of a „voids-pillar“ structure excavated by means of the sub-level stoping method in an underground limestone quarry near Bergamo (Italy). Both the current structure of the quarry (i.e. the rooms exploited till now) and a possible future scenario were analysed using the (FDM) FLAC 2D code. The quarry has been in operation since 1927; at present, exploitation is carried out underground via the sub-level stoping method. Exploitation involves two levels, with 5 rooms on the upper level and 9 rooms on the lower level.

After analysing data obtained from laboratory and in situ tests carried out on rock samples and natural discontinuities, the geomechanical properties of the medium, knowledge of which is essential in order to establish the parameters that must be included in the numerical model, were evaluated.

The implementation of three numerical models made it possible to study both the present conditions of quarry exploitation and the evolution of the exploited rooms, as well as a possible expansion involving a third level of rooms. Using the results obtained regarding the stress-strain present in the pillars, a potential change in room geometry was proposed aimed at reducing the stress state inside the pillars, decreasing plasticity and increasing overall quarry safety.

Keywords: underground exploitation, sub-level stoping, stress-strain conditions, safety factor, numerical modelling, mining method

Celem pracy było zbadanie stanów naprężeń w strukturach składających się z filarów i pustek po wybieraniu wapienia w podziemnym kamieniołomie w pobliżu Bergamo (Włochy), metodą wybierania podpoziomowego. Zarówno obecna struktury kamieniołomu (komory powstałe po dotychczasowym wydobyciu) oraz możliwe scenariusze na przyszłość przeanalizowano przy użyciu kodu (FDM) FLAC 2D. Eksploatacja kamieniołomu trwa od 1972, w chwili obecnej wydobycie odbywa się pod ziemią, metodą wybierania podpoziomowego, na dwóch poziomach wybierania: 5 komór na poziomie wyższym i 9 komór - na niższym.

* POLITECNICO DI TORINO CORSO DUCA DEGLI ABRUZZI, 24-10129, TORINO, ITALY.

** IGAG CNR, TORINO, ITALY.

*** MINING ENGINEER, VERBANIA, ITALY.

1 CORRESPONDING AUTHOR. E-MAIL: pierpaolo.oreste@polito.it 
Po analizie danych uzyskanych drogą testów laboratoryjnych oraz badania w terenie próbek skalnych i stref nieciągłości, określono właściwości geomechaniczne ośrodka niezbędne do obliczenia parametrów do modelu numerycznego.

Implementacja trzech modeli numerycznych umożliwiła analizę zarówno obecnych warunków eksploatacji kamieniołomu, procesów zachodzących w wyeksploatowanych komorach, jak i projektowanie ewentualnego rozszerzenia wydobycia, w tym powstanie trzeciego poziomu. Wykorzystując otrzymane zależności naprężeń i odkształceń, zaproponowano zmiany w geometrii komór mające na celu obniżenie poziomu naprężeń $\mathrm{w}$ filarach, zmniejszenie ich podatności i ogólne podniesienie stanu bezpieczeństwa w kamieniołomie.

Słowa kluczowe: eksploatacja podziemna, wybieranie podpoziomowe, stan naprężeń i odkształceń, współczynnik bezpieczeństwa, modelowanie numeryczne, metoda wybierania

\section{Introduction}

The quarry under study, which is located in Northern Italy, has been active since 1927 and currently supplies a large lime, 4 vertical kilns plant with a total annual burned lime production of $350,000 \mathrm{t} / \mathrm{y}$. Owing to the burning loss $(50 \%)$ and the fines $(<10 \mathrm{~mm})$ that clog the kilns and which must be discarded before burning, around $106 \mathrm{t} / \mathrm{y}$ of blasted rock $\left(380,000 \mathrm{~m}^{3} / \mathrm{y}\right.$ of rock in place) must be guaranteed. This in turn means working an average daily production of 4,000 to 5,000 $\mathrm{t}$ for 220 days/y. However, as the burning process is continuous and momentary shortages in supply cannot be tolerated, an appropriate daily production rate of $2,000 \mathrm{~m}^{3} / \mathrm{d}$ (in place) is requested. Primary and secondary crushing, sieving and washing plants have been located underground since the original surface exploitation period. Underground exploitation is currently conducted in order to reduce waste removal, as can be seen in Figure 1.

Limestone is abundant in the area, but only one member of the stratigraphic succession is in fact suitable for the production of quicklime: a 160-180 m thick bed of very pure limestone. The other beds are either too rich in magnesia and/or silica (Table 1). As Figure 1 illustrates, the bed is sub-vertical; in order to continue surface quarrying it would thus be necessary to remove an increasing amount of unsuitable limestone for stability reasons (Oriard, 1982). This removal would not only increase the ratio of useless excavated rock to pure limestone, and, obviously, the cost of exploitation, but would also in fact be impossible, because there is not enough free space to dump the resulting large volumes of waste rock (Berta et al., 1999). Underground exploitation could therefore instead be favourably considered (Mancini et al., 2003; Mancini et al., 2005); here the limestone is sound in thick beds, the RQD is close to $100 \%$ and wide stopes can be opened along the longer axis at a right angle to the bedding, which is separated by pillars of adequate width. The percentage recovery of the rock body would obviously be low compared to that of surface exploitation, but could still guarantee, within the permitted limits, 20 years of production at the present rate.

TABLE 1

Mean percentages of the constituents of the exploited limestone

\begin{tabular}{|c|c|c|c|}
\hline \hline Calcite & Dolomite & Silica & Impurities \\
\hline $\mathrm{CaCO}_{3}$ & $\mathrm{CaMg}\left[\mathrm{CO}_{3}\right]_{2}$ & $\mathrm{SiO}_{2}$ & $\mathrm{Al}_{2} \mathrm{O}_{3}-\mathrm{Fe}_{2} \mathrm{O}_{3}-\mathrm{Na}_{2} \mathrm{O}-\mathrm{K}_{2} \mathrm{O}$ \\
\hline $96.5-97.5 \%$ & $1.5-2.0 \%$ & $0.2 \%$ & $1.0-1.5 \%$ \\
\hline
\end{tabular}




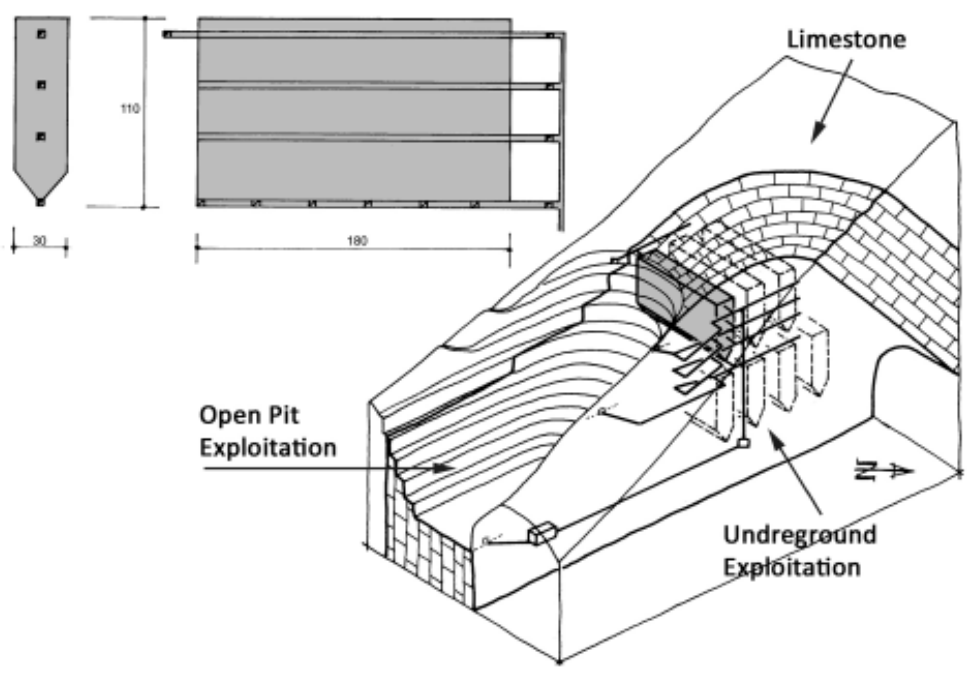

Fig. 1. 3D scheme of the rock body, surface exploitation and underground exploitation; the increase in waste removal required to continue surface exploitation can be observed (Mancini et al., 2005)

\subsection{Mining method}

A sub-level stoping method has been adopted (Lawrence, 2007), with haulage by means of conveyor belts. The blasted rock is taken from the draw-points by LHD machines and transferred to a mobile crusher, before being sent to the conveyor belt - ore pass system; the lower stopes are exploited in largely the same way, but here haulage is conducted by means of LHD + dumper tracks and the primary crusher is installed in a fixed position. A general plan of the quarry is shown in Figure 2; only 6 of the 13 stopes have been exploited thus far.

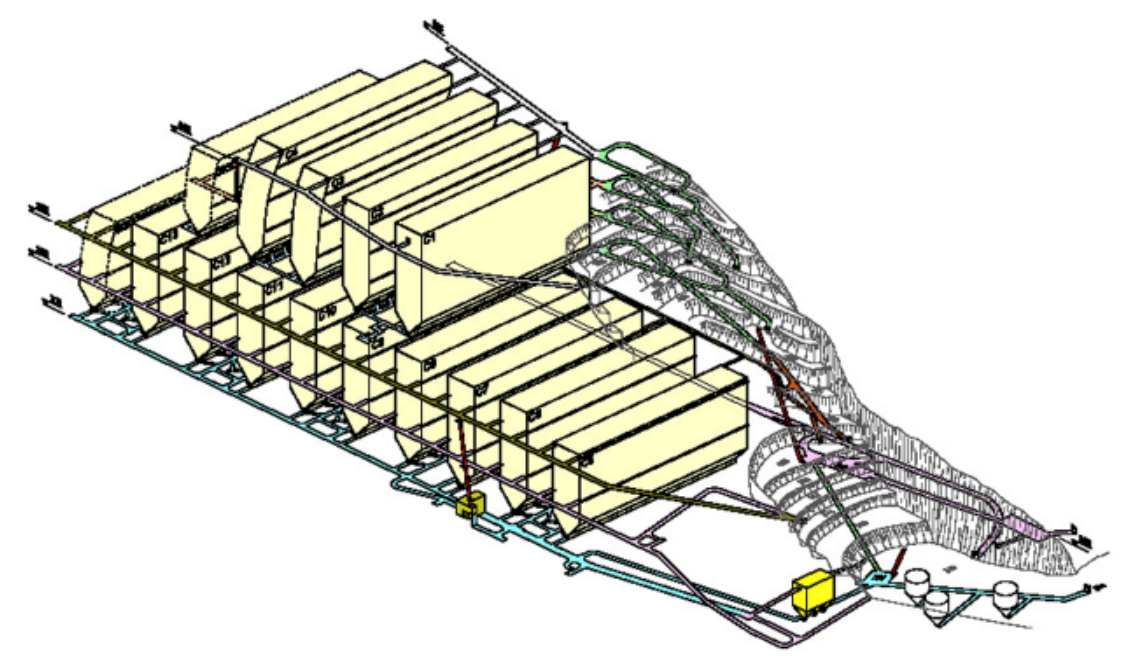

Fig. 2. 3D view of the rooms, at the end of exploitation (Mancini et al., 2005) 


\subsection{Geomechanical properties of the rock mass}

According to the results of surveys conducted for the earlier surface exploitation and in development tunnels, the geomechanical quality of the rock mass can be considered good.

In order to transpose the rock mass into a continuous and homogeneous medium, which is necessary to implement the numerical model, it was essential to analyse it in terms of its geomechanical behaviour.

Limestone mechanical strength data were obtained by means of extensive coring (Table 2). JCS (Joint Compressive Strength) was considered equal to $80 \mathrm{MPa}$. Using the previous data and a discontinuities survey, the rock mass was classified as shown in Table 3. A rock mass classification value of around 70 was determined based on the GSI method (Hoek \& Diederichs, 2006; Hoek \& Brown, 1980), with this value comparable to the RMR (Bieniawski, 1979, 1983, 1989) considering the formula that links the two methods: GSI = RMR-5.

Mechanical characteristics of the rock mass (intact rock)

\begin{tabular}{|l|c|}
\hline \hline Density $\gamma$ & $2.67 \mathrm{t} / \mathrm{m}^{3}$ \\
\hline Average uniaxial compressive strength $C_{0}$ & $135 \mathrm{MPa}$ \\
\hline Average Brazilian strength $T_{0}$ & $6.9 \mathrm{MPa}$ \\
\hline Young's modulus $E_{t}$ & $81054 \pm 4395 \mathrm{Mpa}$ \\
\hline Poisson Ratio $v$ & 0.306 \\
\hline Cohesion $C_{i}$ & $40-45 \mathrm{Mpa}$ \\
\hline Internal friction angle $\varphi$ & $28^{\circ}$ \\
\hline
\end{tabular}

TABLE 3

Rating of each parameter in the Rock Mass Rating System RMR

\begin{tabular}{|l|c|}
\hline \multicolumn{1}{|c|}{ Parameter } & Rating \\
\hline Uniaxial compressive strength (MPa) & $12 / 15$ \\
\hline RQD (\%) & $20 / 20$ \\
\hline Spacing of discontinuities (m) & $15 / 20$ \\
\hline Condition of discontinuities & $16 / 30$ \\
\hline Ground water & $15 / 15$ \\
\hline Total rating & $78 / 100$ \\
\hline
\end{tabular}

Due to the high lithological homogeneity and structural uniformity of the limestone, data obtained from in situ and laboratory tests performed on samples of undisturbed rock were considered representative of the whole rock mass.

Some small karstic cavities were crossed during the development works in the upper levels, but groundwater problems were not encountered or expected, as the water table position is influenced by the river bed (290 m a.s.l) while the foreseen exploitation develops at altitudes higher than $305 \mathrm{~m}$ a.s.1. The quarry has been designed according to the same principles that are followed when designing a multi-stage building in masonry, with pillars considered as walls subjected to both vertical (the rock cover plus its own weight) and horizontal loads (the unbalanced lateral thrust of the self-supporting vaults connecting the pillars) (Persson et al., 1994; 
Guarascio \& Oreste, 2012; Oreste, 2012); a rock thickness of $2 \mathrm{~m}$ adjacent to the wall surface without strength has been considered as a load, as it has been overstressed due to the proximity of the blasts.

\subsection{Evolution of the exploitation}

As mentioned above, the 14 rooms are arranged on two levels (Fig. 3); rooms C1, C2, C3 and C6 have been completed, rooms $\mathrm{C} 4$ and $\mathrm{C} 5$ are currently under exploitation, and the remaining 8 rooms are yet to be started. The first stope $(\mathrm{C} 1)$ has been exploited using one drilling tunnel per sub-level, that is, 3 drilling tunnels per stope, as shown in the right of Figure 4 . This arrangement was chosen with the aim of minimising the development work and reducing the width of the stope, in case of an unforeseen reduction in the self-supporting ability of the roof (Stiehr \& Dean, 2011).

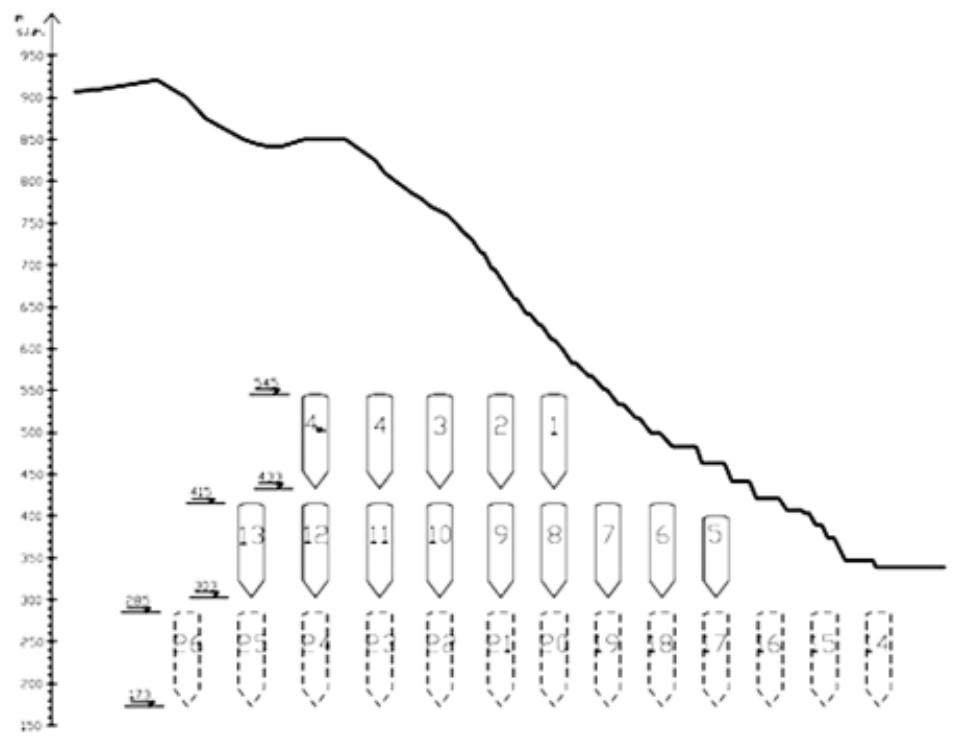

Fig. 3. Longitudinal section of the quarry rooms; the continuous lines depict those rooms currently planned, and the dotted lines those assumed in a hypothetical development of the exploitation

A number of drawbacks (all of which were successfully overcome) became apparent during exploitation: slotting was difficult and time consuming; the side walls of the open stope were often very irregular due to poor or excessive failure at the toe of the holes; and the round included a great number of long upward holes, which were difficult to drill and charge. Although the results were still acceptable, starting from stope no. 2 a different scheme was adopted involving the use of two drilling tunnels in each sub-level (Fig. 4, left), resulting in more preparatory work but better control of pillar size and strength; other changes (increasing the sub-level spacing and the size of the production blasts) were also made so that the rooms located at the present lower level could be realised with two sub-levels and two drilling tunnels for each sub-level (Fig. 5, left). 


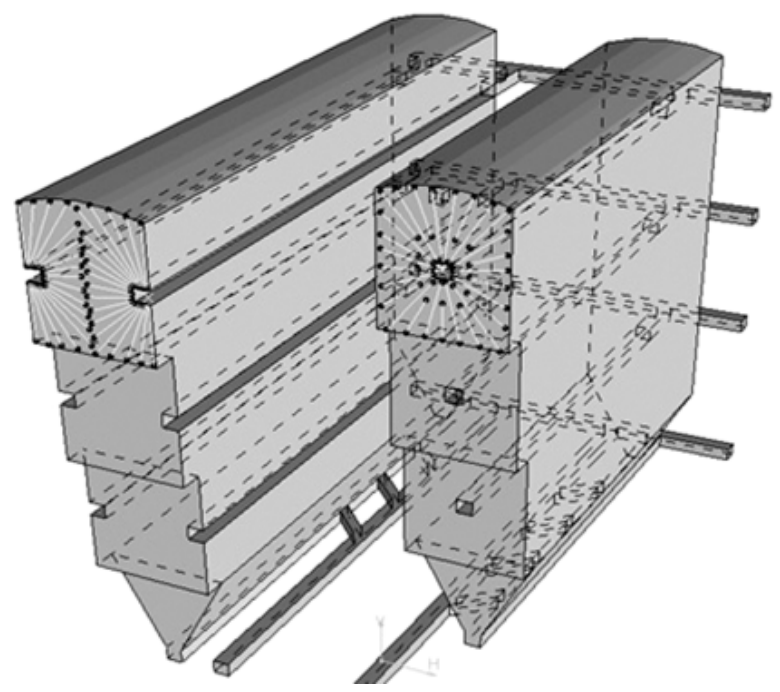

Fig. 4. Right: Exploitation with 3 sub-levels and one drilling tunnel per sub-level; left: The same scheme with 2 drilling tunnels per sub-level (Mancini et al., 2003; Mancini et al., 2005)

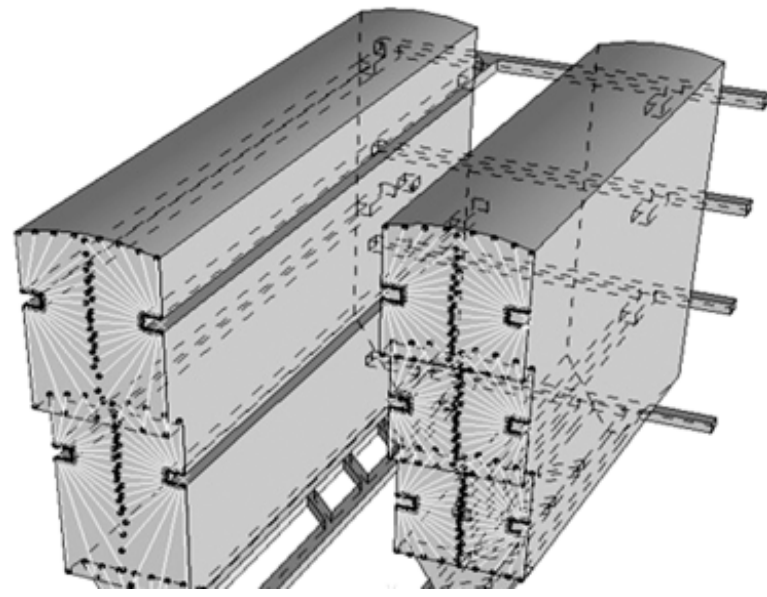

Fig. 5. Left: Exploitation with 2 sub-levels and 2 drilling tunnels per sub-level; right: The same scheme with 3 sub-levels (Mancini et al., 2003; Mancini et al., 2005)

Current production blasts have been designed for 2,700 to $3,000 \mathrm{~m}^{3}$ rock volumes each. The basal collecting trough has been produced with smaller blasts, with some rounds in advance of those exploited, as shown in Figure 5. Draw points have been spaced every $20 \mathrm{~m}$. Blasted rock is collected in 7-9 $\mathrm{m}^{3}$ LHD loaders, carried to the mobile crusher and fed to the belt-ore pass system.

Stope average volume is 500,000 to $550,000 \mathrm{~m}^{3}$ (the width being $30 \mathrm{~m}$, the length $180 \mathrm{~m}$ and the height $110 \mathrm{~m}$ ), for 1.4 years of production. This means that a new stope must be ready (i.e. the drilling tunnels prepared and the slot opened) before the previous one is finished, a pace 
that has thus far proven possible. The total workforce amounts to 15 (some hired from an external contractor) and the machinery comprises 2 jumbos, 1 Solo drill (for production drilling), 2 Toro LHD $\left(7 \mathrm{~m}^{3}\right.$ and $\left.9 \mathrm{~m}^{3}\right), 1$ mobile crusher and belting (the haulage system is due to be replaced).

\section{The two-dimensional numerical model}

Numerical modelling was performed using FLAC 2D (Fast Lagrangian Analysis of Continua) Version 4.00 SP (Itasca Consulting Group 2005, 2010) in order to verify the adequacy of the size of the pillars between the quarry rooms. FLAC 2D is a two-dimensional application typically employed in association with Explicit Finite-difference methods (FDM). The problem is typically of $3 \mathrm{D}$ type but, being the geometry regular along the axis of the chambers under exploitation, studies of $2 \mathrm{D}$ type can be developed without making significant errors. Some specific procedures are used, in order to simulate the actual excavation through 2D numerical modelling.

\subsection{Parameters employed in the numerical model}

In order to use Mohr-Coulomb (M-C) elastic and elastoplastic constitutive models, the following 7 parameters were considered necessary for the numerical model:

1) Density $=2.67 \mathrm{~g} / \mathrm{cm}^{3}=0.00267 \mathrm{Mkg} / \mathrm{m}^{3}$

2-3) Volumetric strain modulus $K$ and shear strain modulus $G$, having defined the Elastic modulus $E$ via the Serafim Pereira equation [4]:

$$
\begin{gathered}
E=10 \frac{R M R-10}{40}=42.17 \mathrm{GPa}=42170 \mathrm{MPa} \\
K=\frac{E}{3 \cdot(1-2 \cdot v)}=36228 \mathrm{MPa} \\
G=\frac{E}{2 \cdot(1+v)}=16145 \mathrm{MPa}
\end{gathered}
$$

4) Friction angle: $\varphi=5+(\mathrm{RMR} / 2)=42.5^{\circ}$

5) Dilatancy angle, which is irrelevant in the elastic case, with an intermediate value between zero and that routinely used ( $1 / 3$ of the friction angle) taken: $\psi=8^{\circ}$.

6) Cohesion: $c=4 \mathrm{MPa}$, which is an intermediate value between that derived using the Bieniawski relationship ( $c=5 \cdot \mathrm{RMR})$ and that resulting from the Mohr-Coulomb failure envelope (intercept of the straight line with the $x$-axis on the $\sigma_{1}-\sigma_{3}$ plane).

7) Tensile strength, obtained by means of the Mohr-Coulomb failure envelope.

First, the stress-strain behaviour of the rock mass resulting from room excavation (C1-C13) was studied. The numerical model has a width of $1200 \mathrm{~m}$ and a height of $1000 \mathrm{~m}$, with a total of 300,000 square elements $(2 \mathrm{~m} \times 2 \mathrm{~m})$. Model dimensions were evaluated taking into account the size of the area affected by exploitation, whilst maintaining a clearance distance of more than $200 \mathrm{~m}$ on all sides in order to prevent the model edges from affecting room excavation, which would negatively affect the results (Coulthard, 1999; Jing \& Hudson, 2002). The upper edge of the model is represented by the topographic surface. 
The calculation steps initially caused the model to assume lithostatic load conditions. After each calculation phase it was verified that the model converged due to the virtually nil speed of the nodes. Successive room excavation stages were then established, using the actual sequence of implementation. Excavation was simulated by degrading the stiffness characteristics of the elements included in the excavation areas, reducing them by $20 \%$ at each step until they were cancelled (having previously defined the closed regions that represent the rooms on the grid).

\subsection{Analysis of results}

The numerical processing output reflects the stress-strain state of individual elements and the displacement of nodes. Trends of the horizontal and vertical stresses are shown in Figures 6, 7 and 8 , together with the plasticised zones at the end of the exploitation.

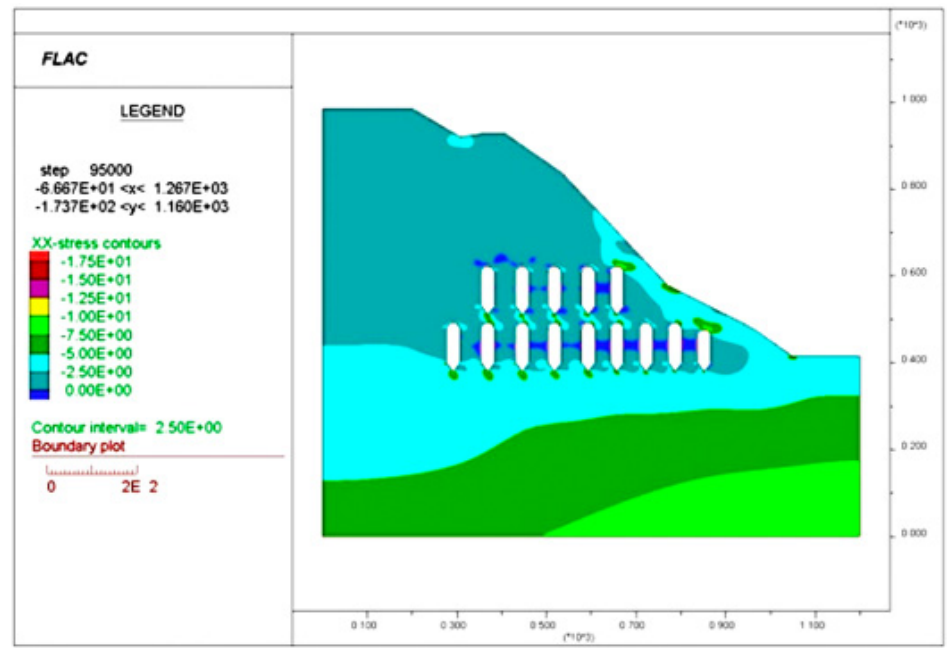

Fig. 6. Horizontal stresses $\sigma_{x x}$ at the end of the exploitation (MPa) according to the Mohr-Coulomb strength criterion

Horizontal stresses are almost null in the pillars between the rooms, especially in the central part, as the slabs interrupt their continuity; the slabs are in fact compressed horizontally (the stress levels, however, are 4 to 5 times greater than in the vertical pillars). The crowns of rooms $\mathrm{C} 1$ and $\mathrm{C} 5$, that is, the most superficial ones, are also squeezed horizontally. Pillar vertical stresses appear to increase from the upper to the lower level and towards the inner part of the mountain. This pattern largely reflects the increase in overburden. The most critical pillar is located between rooms $\mathrm{C} 12$ and $\mathrm{C} 13$. However, the slabs between the two levels are almost unloaded as far as the stresses acting in the vertical direction are concerned.

Finally, the figures illustrate how the plasticised zones generally increase from the top to the bottom floor, and from right to left (with increasing overburden and, consequently, stress levels). The crowns of rooms $\mathrm{C} 1$ and $\mathrm{C} 5$, which are closest to the slope, are exceptions, as they exhibit greater plasticisation than the outlined trend. 


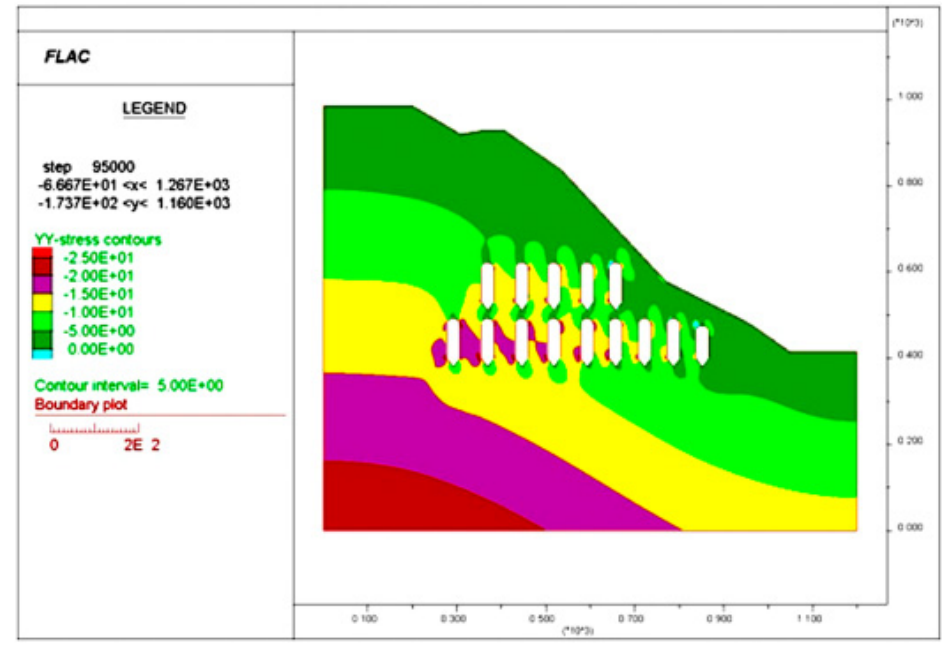

Fig. 7. Vertical stresses $\sigma_{y y}$ at the end of the exploitation (MPa) according to the Mohr-Coulomb strength criterion

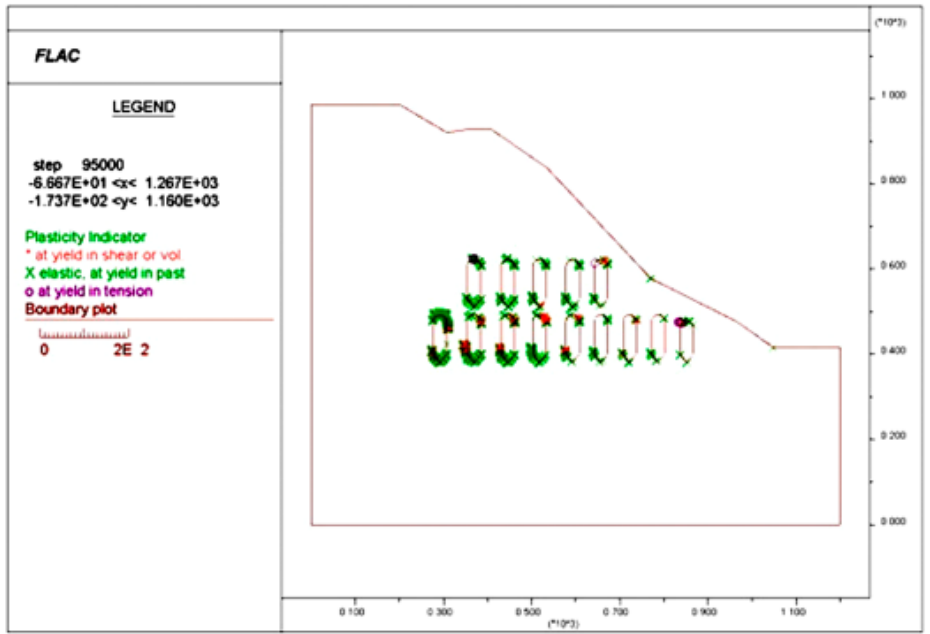

Fig. 8. Plasticised zones at the end of the exploitation according to the Mohr-Coulomb strength criterion

The sector exceeding the elastic limit around the rooms is concentrated in the crown and collection trough; this zone has a thickness of 2 to $3 \mathrm{~m}$ (estimated here as deteriorated rock, as it has no bearing capacity) for rooms $\mathrm{C} 1$ to $\mathrm{C} 9$ (5 rooms on the upper floor and the right-most 5 on the lower floor), increasing to between 4 and $6 \mathrm{~m}$ in some parts of rooms $\mathrm{C} 10$ and $\mathrm{C} 11$.

There are two plasticisation areas extending for 8 to $10 \mathrm{~m}$ in the pillar between the last two rooms (C12 and C13), the pillar itself being $47 \mathrm{~m}$ wide. This could represent the early stages of oblique fracture development. The most critical situation is therefore that of the pillar, which will remain in place between the last two exploited rooms. 
In order to analyse the stress state of this pillar (the most stressed region in the whole model), the performance of the safety factor was evaluated along 4 different alignments (altitudes of 333 , 353, 373 and 393 m a.s.1. - Fig. 9).

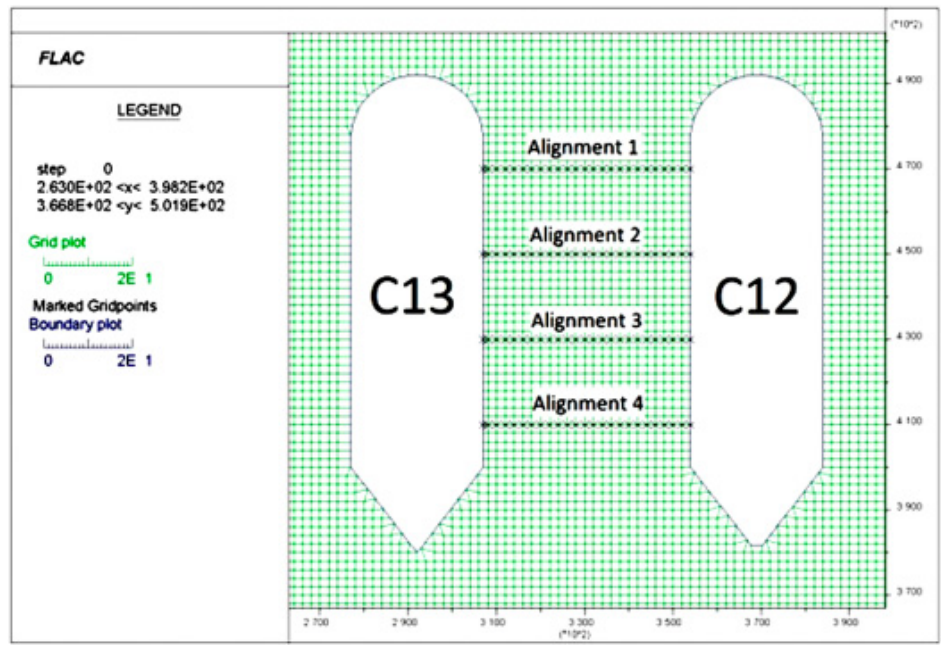

Fig. 9. Alignments considered for the assessment of pillar safety factor values

The maximum and minimum principal stresses were calculated for each node of the 4 alignments, thereby enabling the corresponding point on plane $\sigma_{1}-\sigma_{3}$ to be found. The failure envelope was evaluated on the same plane: the safety factor was then calculated as a function of the distance of the failure envelope from that point:

$$
S F=y_{i} / \sigma_{1, i}
$$

where $y_{i}$ represents the rock mass strength at the point with abscissa $\mathrm{i}$ (the value of the minimum principal stress) and $\sigma_{1, i}$ is the value of the maximum principal stress.

The trend of SF was calculated for the 4 alignments based on the Mohr-Coulomb linear failure envelope (Fig. 10) and the Hoek \& Brown (H-B) curvilinear envelope (Hoek et al., 2002). In the latter case, the failure curve was calculated using both parameters $\mathrm{s}$ and $\mathrm{m}$, which were obtained via the undisturbed (Fig. 11) and disturbed rock-mass (Fig. 12) formulas (the considered $\mathrm{m}_{\mathrm{i}}$ parameter was equal to 10 , an averaged value for limestone).

As far as the uppermost alignment is concerned, it can be seen that the SF becomes virtually unitary for the first few metres due to the presence of the plastic zones (see Fig. 8), then tends to increase towards the centre of the pillar, reflecting the positive impact of the confinement induced by the slight increase in horizontal stresses, before finally decreasing again approaching the next room. A similar situation, but in reverse, can be noted for the lowest alignment (no. 4). The two central alignments exhibit a more constant trend of SF values, which are fairly low at between 1.13 and 1.09 .

When applying the Hoek \& Brown envelope, it can be observed that the safety factors are greater in the first scenario (undisturbed conditions), with values almost always greater than 2 


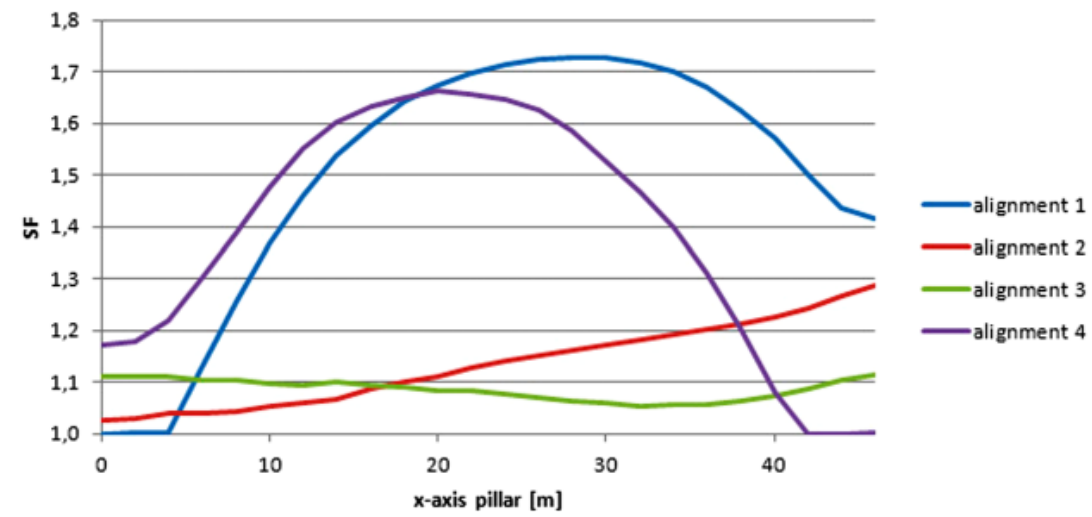

Fig. 10. Trend of SF for the 4 alignments with reference to the M-C strength criterion

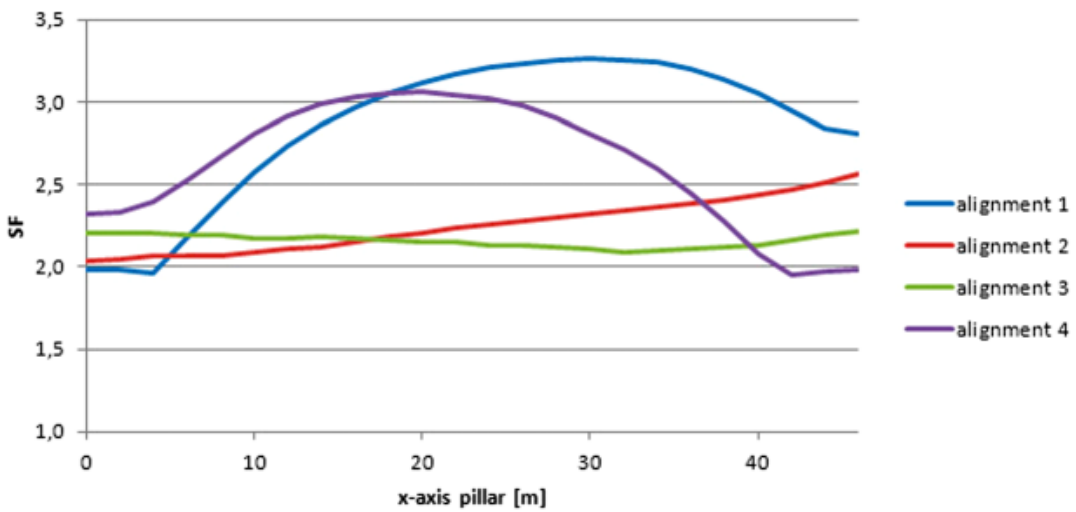

Fig. 11. Trend of SF pertaining to the 4 alignments with reference to the H-B strength criterion (undisturbed conditions)

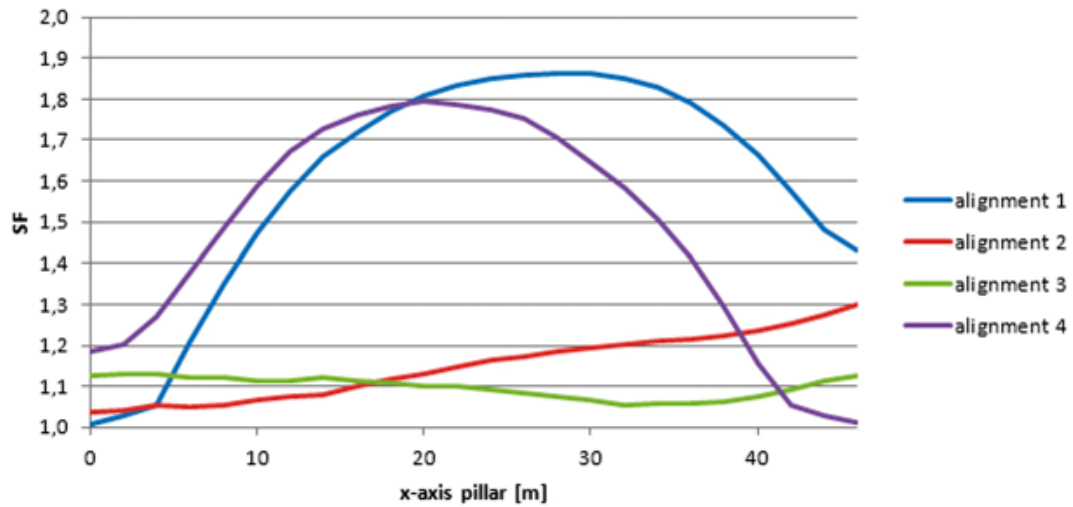

Fig. 12. Trend of SF pertaining to the 4 alignments with reference to the H-B strength criterion (disturbed conditions) 
at each point (Fig. 11). In the second scenario ( $\mathrm{m}$ and $\mathrm{s}$ under disturbed conditions), SF values are slightly higher than those obtained by applying the Mohr-Coulomb envelope, and the same considerations apply (Fig. 12). For the sake of clarity and comparability, the results are summarised in Table 4.

TABLE 4

Average SF values obtained for the analysed alignments and percentage plasticisation in each alignment

\begin{tabular}{|c|c|c|c|c|}
\hline \hline \multirow{2}{*}{$\begin{array}{c}\text { Alignment } \\
\text { [n.] }\end{array}$} & \multicolumn{3}{|c|}{ Average SF } & $\begin{array}{c}\text { Plasticisation } \\
{[\%]}\end{array}$ \\
\cline { 2 - 4 } & M-C & H-B Und.. & H-B Dist. & 8.5 \\
\hline 1 & 1.50 & 2.85 & 1.60 & 0.0 \\
\hline 2 & 1.13 & 2.25 & 1.15 & 0.0 \\
\hline 3 & 1.09 & 2.16 & 1.10 & 10.6 \\
\hline 4 & 1.39 & 2.62 & 1.48 & \\
\hline
\end{tabular}

Considering these findings, it was decided to evaluate SF in two pillars on the same level (C12-C11 and C11-C10), paying particular attention to the central portion (where the situation is more critical due to the lower lateral confinement) and to the method producing the most cautionary data, namely the Mohr-Coulomb envelope. The results of this analysis are presented in Tables 5 and 6.

TABLE 5

Average SF values obtained for pillar C12-C11, evaluated using the 3 proposed methods

\begin{tabular}{|c|c|c|c|}
\hline \hline \multirow{2}{*}{$\begin{array}{c}\text { Alignment } \\
\text { [n.] }\end{array}$} & \multicolumn{3}{|c|}{ SF } \\
\cline { 2 - 4 } & M-C & H-B Und. & H-B Dist. \\
\hline 1 & 1.58 & 3.02 & 1.69 \\
\hline 2 & 1.20 & 2.39 & 1.21 \\
\hline 3 & 1.16 & 2.30 & 1.17 \\
\hline 4 & 1.47 & 2.79 & 1.57 \\
\hline
\end{tabular}

Average SF values obtained for pillar C11-C10, evaluated using the 3 proposed methods

\begin{tabular}{|c|c|c|c|}
\hline \hline \multirow{2}{*}{$\begin{array}{c}\text { Alignment } \\
\text { [n.] }\end{array}$} & \multicolumn{3}{|c|}{ SF } \\
\cline { 2 - 4 } & M-C & H-B Und. & H-B Dist. \\
\hline 1 & 1.59 & 3.07 & 1.69 \\
\hline 2 & 1.24 & 2.46 & 1.25 \\
\hline 3 & 1.19 & 2.36 & 1.19 \\
\hline 4 & 1.46 & 2.79 & 1.55 \\
\hline
\end{tabular}

For the first pillar (C12-C11), the lowest SF values are associated with alignment 3; again, further analysis is necessary, but caution must be taken when evaluating the possibility of exploiting room $\mathrm{C} 12$.

For the second pillar (C11-C10), SF values decrease to almost 1.2; given the very precautionary assumptions with which the parameters introduced in the numerical model were calculated, and considering that the most precautionary method was well thought-out, stress conditions in this pillar can be assumed acceptable. 


\section{Expansion proposals: two-dimensional numerical room model}

In order to analyse a possible expansion of quarry exploitation to a third level, another numerical model including 13 hypothesised new rooms (from C14 to C26, see Fig. 3) was developed.

The results of this analysis, expressed in terms of horizontal and vertical stresses and of yielded (plasticised) zones, are shown in Figures 13, 14 and 15.

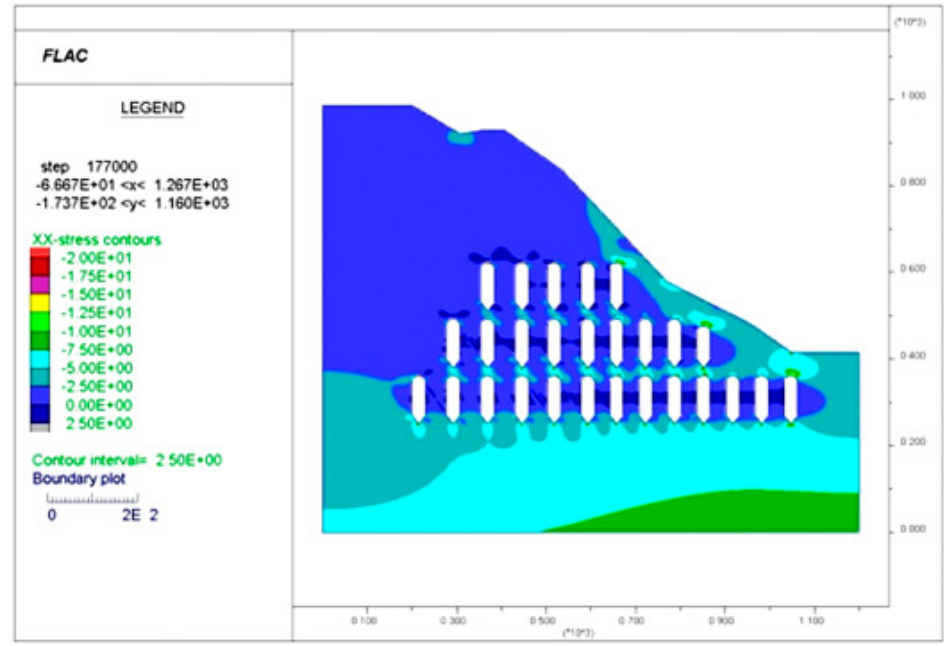

Fig. 13. Horizontal stresses $\sigma_{x x}$ at the end of the exploitation (MPa) according to the Mohr-Coulomb strength criterion

Establishing the uncertainty of the input data is a prerequisite for accurate analysis of the results, especially regarding the additional voids, which at present have not been included in the ore-body exploitation project; unfortunately no information is currently available regarding the integrity of the material or the groundwater level (an important river flows in the vicinity of the quarry). As a result, the material values employed previously and the absence of an aquifer were therefore assumed, considering their extrapolation is valid. Given these assumptions, it is obvious that the results obtained for this hypothetical third level can be considered only as a preliminary indicator of the possible behaviour of the rock mass as a result of exploitation. If in the future this possibility were to be pursued, it would be necessary to correct the input data in the numerical model via an adequately careful new investigative campaign.

Analysis of Figures 13, 14 and 15 reveals that the calculated stress trend is similar to that expected; levels rise with the deepening of the rooms on the lower level and from right to left, as the lithostatic load increases in this direction.

The yielding zone that develops around the inner rooms on this level (from rooms C21 to $\mathrm{C} 26)$ is highly developed and involves all the pillars that would remain in place.

Furthermore, given the proximity of the last chamber (C26) to the failure, the presence of a more fractured rock mass (quantitative information regarding this area is not currently avail- 


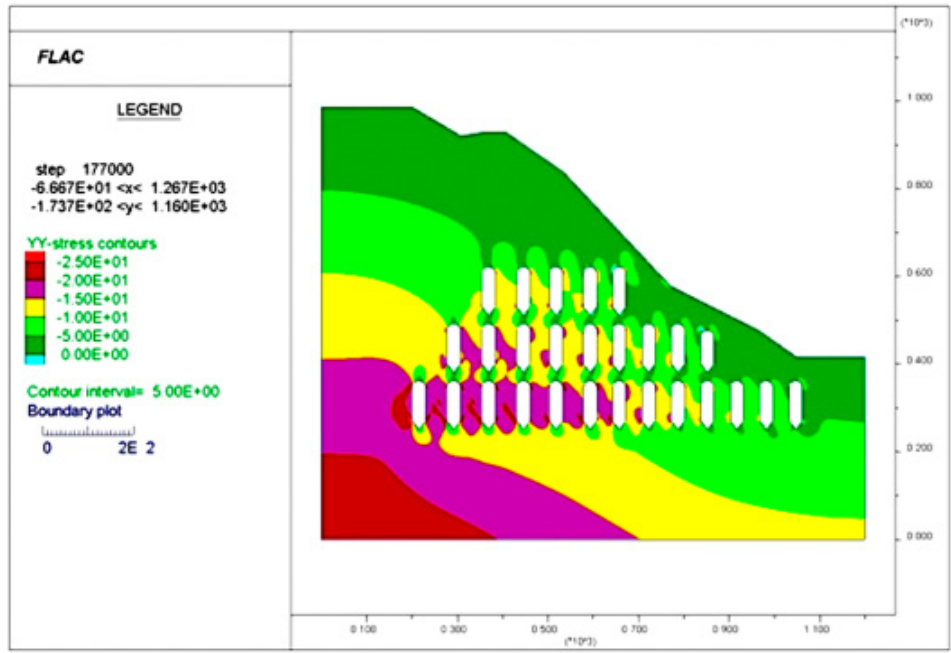

Fig. 14. Vertical stresses $\sigma_{y y}$ at the end of the exploitation (MPa) according to the Mohr-Coulomb strength criterion

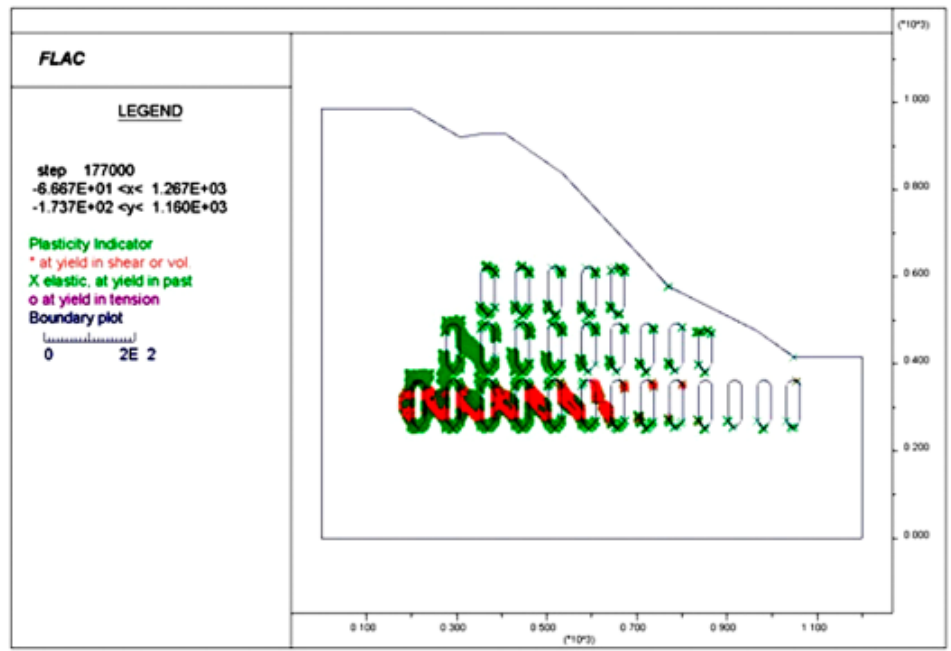

Fig. 15. Plasticised zones at the end of the exploitation according to the Mohr-Coulomb strength criterium

able) would make it impossible to guarantee this room's safe and cost-effective exploitation. The penultimate pillar between rooms C24 and C25 was therefore analysed in more detail. It should be noted that conditions here are more onerous, from a qualitative point of view, than those of the overlying pillar and thus the safety factor value is consequently lower. The plastic band is also much larger and the creation of a possible oblique failure plane inside the pillar is almost certain. Again, 4 horizontal alignments located at different heights (203, 223, 243 and $263 \mathrm{~m}$ a.s.1.) were considered (Fig. 16). 


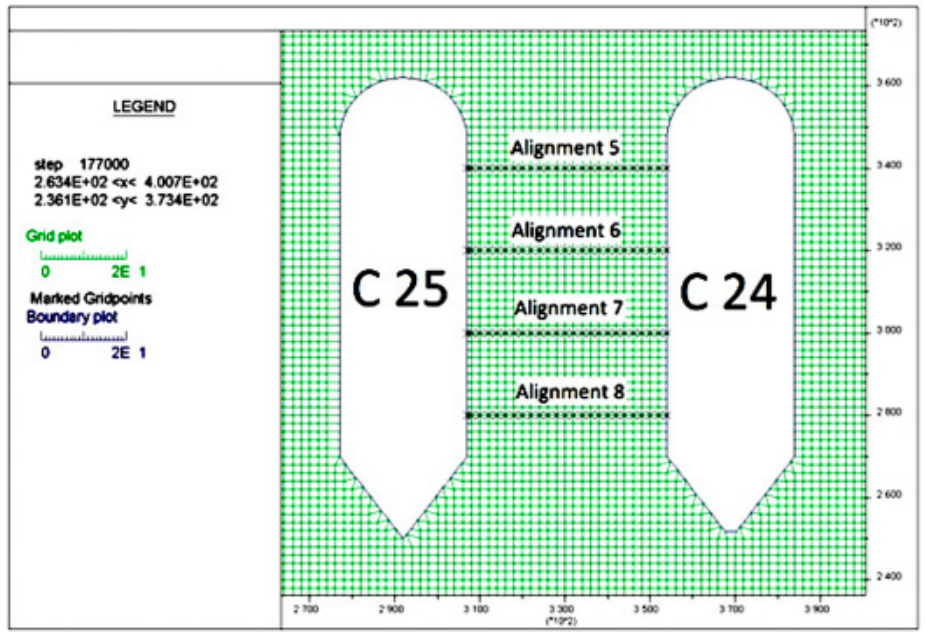

Fig. 16. Alignments considered for the assessment of pillar SF values

The method adopted for the calculation of SF was the same as that explained previously; the obtained results are shown synthetically in Table 7.

TABLE 7

Average SF values obtained for the analysed alignments and percentage plasticisation in each alignment

\begin{tabular}{|c|c|c|c|c|}
\hline \hline \multirow{2}{*}{$\begin{array}{c}\text { Alignment } \\
\text { [n.] }\end{array}$} & \multicolumn{3}{|c|}{ SF } & Plasticisation \\
\cline { 2 - 4 } & M-C & H-B Und. & H-B Dist. & 17.0 \\
\hline 5 & 1.31 & 2.49 & 1.40 & 80.9 \\
\hline 6 & 1.02 & 2.01 & 1.04 & 100 \\
\hline 7 & 1.01 & 1.99 & 1.04 & 27.7 \\
\hline 8 & 1.25 & 2.35 & 1.33 & \\
\hline
\end{tabular}

Although the same observations as those for the previous case $(\S 2.2)$ also apply here, the plastic zone is further expanded and now encompasses the entire area between the two rooms. Safety factor values are on average $10 \%$ lower.

Given the low safety margins obtained using the two more cautious methods, an alternative situation regarding the exploitation of the last room on the second level (as stated in the project) and the hypothesised third level of rooms was proposed, with the aim of reducing the risks related to excessive stress in the pillars.

When changing the position and/or size of the rooms, the pillars must continue to be aligned vertically.

A further geological constraint is the ore-body limit within which the rooms must be kept; in this case the ore-body fold can be represented on the two-dimensional plane of the numerical model as an inclined line passing through the top of the innermost of the three rooms on each level (C4bis, C13 and C26).

As summarised in Figure 17, the proposal involves a $9 \mathrm{~m}$ translation of the last two rooms on the last two levels (together with a $19.2 \%$ increase in pillar thickness from 47 to $56 \mathrm{~m}$ ). Tak- 


\section{4}

ing into consideration the geological constraint at the end of the exploitation, the height of room C13 would decrease from $112 \mathrm{~m}$ to $97 \mathrm{~m}$ (as for room C5). A new numerical model accounting for these changes was used to assess the improvement in SF that this proposal would achieve; the results are summarised in Table 8.

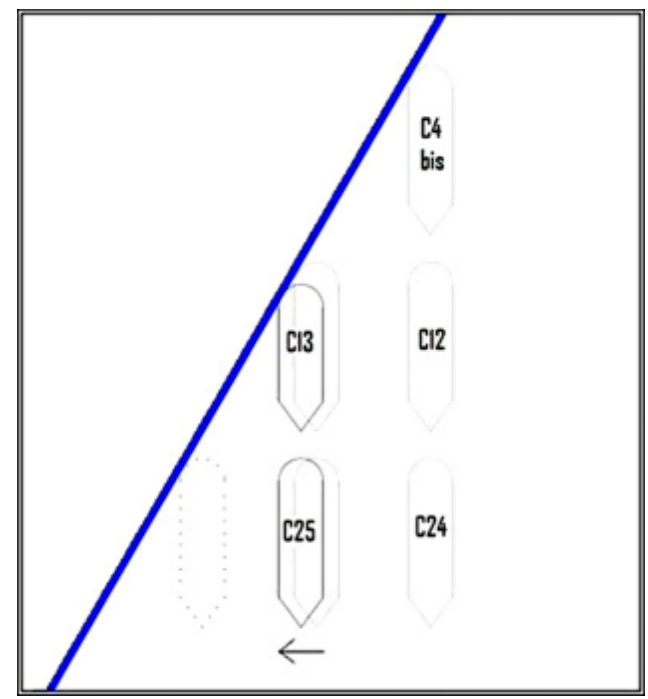

Fig. 17. Proposal for the amendment of the exploitation

Increase in SF value for pillars $\mathrm{C} 12-\mathrm{C} 13$ and $\mathrm{C} 24-\mathrm{C} 25$ after modifying the original project

\begin{tabular}{|l|c|}
\hline \hline Pillar C12-C13 \\
\hline Evaluation method & SF Increase [\%] \\
\hline M-C & +6.94 \\
\hline H-B Undisturbed & +5.98 \\
\hline H-B Disturbed & +8.66 \\
\hline Pillar C24-C25 & SF Increase [\%] \\
\hline Evaluation method & +0.86 \\
\hline M-C & +0.28 \\
\hline H-B Undisturbed & +1.07 \\
\hline H-B Disturbed & \\
\hline
\end{tabular}

The values referring to pillar $\mathrm{C} 12-\mathrm{C} 13$ were calculated only for the 3 lower alignments, as the uppermost alignment was excluded due to the decrease in room size resulting from the proposed change. SF values would increase by an average of $7.2 \%$, reaching $7.8 \%$ when only the two more cautious methods were considered. The proposed project changes would thus improve both void stability and worker safety.

As can be seen, the increase in the distance from the failure curve is much less pronounced for pillar $\mathrm{C} 24-\mathrm{C} 25$, reaching an average of $1 \%$. However, the main advantage arising from the 
change in position of room $\mathrm{C} 25$ is a considerable decrease in rock yield by an average of $15 \%$ across the 4 tested levels; the plastic zones are not continuous inside the pillars. Based on the results of the numerical study, it can be noted that only one half of the total number of hypothesised rooms (those closer to the mountain slope) could be exploited on the third level, due to the heavy plasticisation of the pillars separating the rooms.

\section{Discussion and conclusions}

The characteristics of a quarry site have been analysed, together with the various exploitation methods adopted over the years, in order to assess the implementation of a numerical model. This analysis was undertaken using the FLAC 2D computer code, as it was considered the most suitable with which to realistically characterise the context under study.

As well as those rooms already exploited, a possible expansion of the ore body was also studied, with the mutual interaction between the examined scenarios evaluated. Three numerical models were created and quantitative analysis of the stress state of an evolutionary scenario was carried out.

The first numerical model explored the conditions projected to occur at the end of the exploitation of the planned rooms (C1-C13), with the obtained results revealing the most critical area to be associated with the pillar located between rooms $\mathrm{C} 12$ and $\mathrm{C} 13$.

On this basis, safety factor values for the pillar were calculated at nodes along 4 horizontal alignments located at different altitudes and at the corresponding points on the $\left(\sigma_{1}, \sigma_{3}\right)$ plane, using both the Mohr-Coulomb linear strength and the Hoek-Brown curvilinear strength criteria.

Four curves were thus obtained for each method, showing the SF trend inside the pillar.

The second numerical model analysed the projected expansion of exploitation to a lower level. The results of this analysis revealed that it will not be possible to excavate room C26, given the enormous plasticity at the contour and considering its proximity to the fractured and unstable fold zone.

The SF value of the pillar between rooms $\mathrm{C} 25$ and $\mathrm{C} 24$ was then calculated to be on average $10 \%$ lower than that of the pillar above, with the yield strength more accentuated than at the higher level and appearing continuous from one room to another. Diagonal propagation of plastic zones was also evident, a pattern which could be interpreted as the beginning of a rupture.

A third model was established based on the results obtained from the first two numerical models, in order to evaluate the possibility of shifting the position of rooms $\mathrm{C} 13$ and $\mathrm{C} 25$ to the left by about $9 \mathrm{~m}$ (a value which takes into account the geological limit due to the depletion of the ore body in that direction, as well as operational considerations). This change resulted in an average SF increase in the upper pillar of approximately $7.2 \%$, reaching $7.8 \%$ when only the two more cautious methods were considered.

Taking into account all the constraints (in particular to maintain the pillars on a vertical axis), the results advise against the construction of rooms $\mathrm{C} 13$ and $\mathrm{C} 12$ on the planned second level (303 $\mathrm{m}$ a.s.l.).

With regard to the third (hypothesised) level, the results suggest only the possible expansion of exploitation in rooms C14-C19 should be considered, since expansion elsewhere would certainly cause the elastic limit in the rock mass to be exceeded, thereby resulting in heavy and widespread stability problems. 
However, the present study has revealed that an accurate assessment of rock-mass quality is necessary in that portion of the ore body, in order to verify the characteristics of the material and to ascertain the presence of ground water.

If SF values were still too low, considering the new accurate characterisation, the idea of expanding exploitation to a whole new third level would have to be abandoned, despite the decrease in rock-mass stress.

\section{Acknowledgement}

The authors would like to acknowledge Unicalce SPA - Brembilla and Dr. Vincenzo Piovano for their support provided during the experimental tests.

\section{References}

Berta G., Nasca F., Tamburi M., Cian P., 1999. Impiego di esplosivo per la coltivazione in sotterraneo di una roccia calcarea. Proc. Congr. Attuabilità e Problematiche degli Scavi in Galleria in Italia. A.N.I.M. Verona, Italia, 106-110.

Bieniawski Z.T., 1979. The Geomechanics Classification in Rock Engineering Application. [In:] Proc. 4 th International Congress of Rock Mechanics, Montreux, chap. 5. Balkema, Rotterdam, 55-95.

Bieniawski Z.T., 1983. The Geomechanics Classification (RMR System) in Design Application to Underground Excavation. Proc. International Symposium Eng. Geol. Underground Constr., LNEC, Lisbon, vol. 2, II.33-II.47.

Bieniawski Z.T., 1989. Engineering Rock Mass Classifications: a complete manual for engineers and geologists in mining, civil, and petroleum engineering. John Wiley \& Sons Inc., New York, p. 251.

Coulthard M.A., 1999. Applications of numerical modelling in underground mining and construction. Geotechnical \& Geological Engineering, 17 (3-4), 373-385.

Guarascio M., Oreste P., 2012. Evaluation of the stability of underground rock pillars through a probabilistic approach. American Journal of Applied Sciences, 9 (8), 1273-1282.

Hoek E., Brown E.T., 1980. Underground Excavations in Rock. London: Institution of Mining and Metallurgy.

Hoek E., Carranza-Torres C., Corkumb B., 2002. Hoek-Brown failure criterion. Proc. NARMS-TAC Conference, Toronto, 267-273.

Hoek E., Diederichs M.S., 2006. Empirical estimation of rock mass modulus. International Journal of Rock Mechanics \& Science 43, 203-215.

Itasca Consulting Group, Inc., 2005. FLAC-Fast Lagrangian Analysis of Continua. Ver. 5.0. User's Guide. Minneapolis, USA. Itasca Consulting Group, Inc., 2010. FLAC - Fast Lagrangian Analysis of Continua, Ver. 6. User's Guide. Minneapolis, USA.

Jing L., Hudson J.A., 2002. Numerical methods in rock mechanics. International Journal of Rock Mechanics and Mining Sciences, 39 (4), 409-427.

Lawrence B.W., 2007. Considerations for Sublevel Open Stoping. Underground Methods Handbook, SME, Sec. 2.2, Ch. 2, Stopes Requiring minimum support - Sublevel Stoping, $11 \mathrm{pp}$.

Mancini R., Cardu M., Piovano V., 2003. How the underground quarry design evolves from feasibility study to operation: an analysis of two Italian cases. Proc. Int. Symp. IMBS, Istanbul, 767-774.

Mancini R., Cardu M., Piovano V., Zammarian L., 2005. Sublevel stoping at a large underground quarry: the improvement of the development and exploitation design. 14th International Symposium on Mine Planning and Equipment Selection-MPES, Banff, Canada. Singhal, Fytas, Chiwetelu Ed., 1621-1632.

Oreste P., 2012. Stability of rock pillars with singular and persistent discontinuities. American Journal of Applied Sciences, 9 (9), 1354-1372.

Oriard L.L., 1982. Blasting effects and their control. Underground Mining Methods Handbook, W.A. Hustrulid Ed. Society of Mining, Metallurgy and Exploration, 1590-1603.

Persson D.A., Holmberg R., Lee J., 1994. Rock Blasting and Explosives Engineering. CRC press. New York, U.S.A.

Stiehr J.F., Dean J.L., 2011. ISEE Blasters' Handbook. International Society of Explosives Engineers Ed, 837-869. 